\title{
Structural Features of the Intellectual Potential of the Regions and its Impact on the Development of the Country
}

\author{
Dana M. Kangalakova ${ }^{1 *}$, Dana A. Rakhmetova ${ }^{2}$ \\ ${ }^{I}$ Institute of Economics of the Ministry of Education and Science of the Republic of Kazakhstan, \\ 29 Kurmangazy str., 050010, Almaty, Kazakhstan \\ ${ }^{2}$ Toraighyrov Pavlodar State University, 64, Lomova str., 140008, Pavlodar Kazakhstan
}

\begin{abstract}
In Kazakhstan, the approach to this area is not sufficiently developed, there is no systematic and scientific justification in the management of intellectual resources of the country and regions. Therefore, Kazakhstan is faced with the urgent issue of creating opportunities for the effective use of intellectual capital in the regions, working out management mechanisms and technologies. The development of the region can be traced to the development of intellectual potential in the region. Given the high intellectual potential of the population living in the region, it can be concluded that this region is not lagging in economic development. To determine the potential of the local population, it is necessary to consider the factors influencing it. In this connection, the purpose of this article is to determine the level of factors affecting intellectual potential in the regions of Kazakhstan. During the study, the methods of observation and comparison, system analysis, synthesis and logic were used. In the course of the analysis, it was revealed that in Almaty, Nur-Sultan, Karaganda region, East Kazakhstan region, the components constituting the intellectual potential show a high dynamics of development. There are also regions with low rates of development of components of intellectual potential, these are Almaty region, Akmola region, Turkestan region. For the complex and varied development of regions, appropriate strategic and tactical management decisions should be made, considering the specifics of each region. The factors identified because of the study can become the basis for developing a methodology for assessing the intellectual potential of regions. The research results can be used in programs and strategic plans aimed at developing the intellectual potential of the regions.
\end{abstract}

Keywords: intellectual potential, education, innovation, science, culture, regional development

For citation: : Kangalakova, D.M. \& Rakhmetova, D.A. (2021). Structural Features of the Intellectual Potential of the Regions and its Impact on the Development of the Country. Economics: the Strategy and Practice, 16(3), 22-34, https://doi.org/10.51176/1997-9967-2021-22-34

* Corresponding author: Dana M. Kangalakova - Senior Researcher, Ph.D, Institute of Economics Science Committee of the Ministry of Education of the Republic of Kazakhstan, 050010, Almaty, 29 Kurmangazy str., Kazakhstan, +77016277060, e-mail: dmuratbekovna@mail.ru.

Conflict of interests: the authors declare that there is no conflict of interest.

Financial support: This study has been funded by the Science Committee of the Ministry of Education and Science of the Republic of Kazakhstan (grant IRN AP08052800 "Intellectual potential of the regions of the Republic of Kazakhstan: assessment and development prospects").

The article received: 24.04 .2021

The article approved for publication: 21.06. 2021

Date of publication: 30.09.2021 


\title{
Аймақтардың зияткерлік әлеуетінің құрылымдық ерекшеліктері және оның ел аймақтарының дамуына әсері
}

\author{
Кангалакова Д.М. ${ }^{*}$, Рахметова Д.А. ${ }^{2}$, \\ ${ }^{1}$ Қазақсстан Республикасы Білім және вылым министрлігі Ғылым комитетінің \\ «Экономика институтыл", Шевченко к., 28, 050010, Алматы қ., Қазақсстан \\ ${ }^{2}$ Торайвыров университеті, 64 Ломова к., 140008, Павлодар қ., Қазақсстан
}

\begin{abstract}
Түйін
Ұлттың ақыл-ойының дамуына экономикалық тұрғыдан көптеген қаражат салынады, өздігінен олар ғылымдағы жаңа ашылулармен, өнеркәсіптегі жаңа технологиялармен және елдің ЖІӨ-нің өсуімен қайтарылады. Қазақстанда бұл бағытқа көзқарас жеткілікті мөлшерде дамымаған, елдің және өңірлердің зияткерлік ресурстарын басқаруда жүйелілік пен ғылыми негізділік жоқ. Сол себепті, Қазақстан алдында өңірлердегі зияткерлік капиталды тиімді пайдалануға, басқару тетіктері мен технологияларын пысықтауға мүмкіндік жасау өзекті мәселе болып отыр. Аймақтың дамуын зияткерлік әлеуеттің дамуынан байқауға болады. Аймақта өмір сүретін тұрғылықты халықтың зияткерлік әлеуеті жоғары болса, ол аймақ экономикалық даму бойынша ешқашан артта қалмайды. Тұрғылықты халықтың әлеуетін анықтау үшін оған әсер ететін факторларға көз жүгірту керек. Яғни, мақаланың мақсаты - Қазақстан өңірлеріндегі зияткерлік әлеуетке әсер ететін факторлардың деңгейін анықтау. Зерттеу барысында бақылау және салыстыру, жүйелік талдау, синтез және логикалық әдістер қолданылды. Зерттеу нәтижесінде, мемлекет өңірлеріндегі зияткерлік әлеуетке білім мен ғылымның даму деңгейі, инновация мен мәдениеттілік деңгейі әсер ететіндігі анықталды. Әсер ететін факторлар бойынша аймақтарға талдау жүргізілді. Талдау барысында Алматы қ., Нұр-Сұлтан қ., Қарағанды обл., Шығыс Қазақстан облыстарында зияткерлік әлеуеттің құрамдас бөліктері бойынша даму қарқынды жүруде. Зияткерлік әлеуеттің құрамдас әлеуеттері төмен аймақтар да бар, оларға Алматы обл., Ақмола обл., Түркістан облыстары жатады. Аймақтардың дамуын бірыңғай дамыту үшін әр аймақтың ерекшелігін ескеріп, сәйкесінше стратегиялық, тактикалық басқару шешімдері қабылдану арқылы экономикалық пайда әкелуге болады. Зерттеу нәтижесі ретінде анықталған факторлар әсері аймақтар бойынша зияткерлік әлеуетті бағалау әдістемесін жасауда негіз бола алады. Зерттеу нәтижелері аймақтардағы зияткерлік әлеуетті дамытуға бағытталған бағдарламалар мен стратегиялық жоспарларда қолданыс таба алады.
\end{abstract}

Түйін сөздер: зияткерлік әлеует, білім, инновация, ғылым, мәдениеттілік, аймақтық даму

Дәйексөз алу үшін: Кангалакова Д.М., Рахметова Д.А. (2021), Аймақтардың зияткерлік әлеуетінің құрылымдық ерекшеліктері және оның ел аймақтарының дамуына әсері. Экономика: стратегия және практика, 16(3), 22-34, https://doi.org/10.51176/1997-9967-2021-22-34

* Хат-хабаршы авторы: Кангалакова Дана Муратбековна - аға ғылыми қызметкері, Ph.D, Institute of Economics of the Ministry of Education and Science of the Republic of Kazakhstan, 050010, Almaty, 29 st.Kurmangazy, Kazakhstan., +77016277060, e-mail: dmuratbekovna@mail.ru

Мүдделер қақтығысы: авторлар мүдделер қақтығысының жоқтығын мәлімдейді.

Қаржыландыру. Бұл зерттеуді Қазақстан Республикасы Білім және ғылым министрлігінің Ғылым комитеті қаржыландырды (IRN AP08052800 «Қазақстан Республикасы өңірлерінің зияткерлік әлеуеті: бағалау және даму перспективалары»гранты).

Мақала редакцияға түсті: 24.04 .2021

Жариялау туралы шешім қабылданды: 21.06 .2021

Жарияланды: 30.09.2021 


\title{
Структурные особенности интеллектуального потенциала регионов и его влияние на развитие регионов страны
}

\author{
Кангалакова Д.М. ${ }^{*}$, Рахметова Д.А. ${ }^{2}$ \\ ${ }^{1}$ Институт экономики Комитета науки Министерства образования и науки \\ Республики Казахстан, ул Курмангазы, 29, 050010, г. Алматы, Казахстан \\ ${ }^{2}$ Павлодарский государственный университет им. С. Торайгырова, ул Ломова, 64, \\ 140008, Павлодар, Казахстан
}

\begin{abstract}
Аннотация
В умственное развитие нации вкладывается много средств в экономическом плане, которые сами по себе возвращаются с новыми открытиями в науке, новыми технологиями в промышленности и ростом ВВП страны. В Казахстане недостаточно развит подход к этому направлению, отсутствует системность и научная обоснованность в управлении интеллектуальными ресурсами страны и регионов. Поэтому перед Казахстаном остро стоит вопрос создания возможностей для эффективного использования интеллектуального капитала в регионах, отработки механизмов и технологий управления. Развитие региона можно проследить по развитию интеллектуального потенциала в регионе. При высоком интеллектуальном потенциале проживающего в регионе населения, можно сделать вывод, что данный регион не отстает в экономическом развитий. Чтобы определить потенциал местного населения, необходимо рассмотреть факторы, влияющие на него. В связи с чем цель данной статьи определение уровня факторов, влияющих на интеллектуальный потенциал в регионах Казахстана. В ходе исследования были использованы методы наблюдения и сравнения, системного анализа, синтеза и логики. В ходе анализа выявлено, что в г. Алматы, г. Нур-Султане, Карагандинской области, Восточно-Казахстанской области компоненты составляющие интеллектуальный потенциал показывают высокую динамику развития. Есть также регионы с низкими показателями развития компонентов интеллектуального потенциала, это Алматинская область, Акмолинская область, Туркестанская область. Для комплексного и равномерного развития регионов следует принять соответствующие стратегические и тактические управленческие решения с учетом специфики каждого региона. Выявленные в результате исследования факторы могут стать основой для разработки методики оценки интеллектуального потенциала регионов. Результаты исследования могут быть использованы в программах и стратегических планах, направленных на развитие интеллектуального потенциала регионов.
\end{abstract} развитие.

Ключевые слова: интеллектуальный потенциал, образование, инновации, наука, культура, региональное

Для цитирования: Кангалакова Д.М., Рахметова Д.А (2021). Структурные особенности интеллектуального потенциала регионов и его влияние на развитие регионов страны. Экономика: стратегия и практика, 16(3), 22-34, https://doi.org/10.51176/1997-9967-2021-22-34

* Корреспондирующий автор: Дана Муратбековна - старший научный сотрудник Института экономики Комитета науки Министерства образования и науки Республики Казахстан, 050010, г. Алматы, Курмангазы 29, +77016277060, e-mail: dmuratbekovna@mail.ru.

Конфликт интересов: авторы заявляют об отсутствии конфликта интересов.

Финансирование. Данное исследование финансировалось Комитетом по науке Министерства образования и науки Республики Казахстан (грант IRN AP08052800 “Интеллектуальный потенциал регионов Республики Казахстан: оценка и перспективы развития").

Статья поступила в редакцию: 24.04 .2021

Принято решение о публикации: 21.06 .2021

Опубликовано: 30.09.2021 


\section{Kipicпе}

Қазір әлемде экономикалық дамудың және жаңа технологияларды енгізудің аса жоғары қарқыны басым. Қазақстанның бәсекеге қабілеттілігі үшін өңірлерде және ел деңгейінде зияткерлік әлеует ерекше мәнге ие. Кез-келген мемлекеттің зияткерлік әлеует деңгейін бағалай білу арқылы тұрақты экономикалық дамуды қамтамасыз ететін стратегиялық шешімдерді таңдауға болады. Мемлекет деңгейінде зияткерлік әлеуетті дамыту мен өңірлік деңгейде зияткерлік әлеуетті дамытуды салыстыруға болмайды. Аймақтар бойынша қарастырсақ та, жоғары экономикалық дамыған аймақ пен әлсіз экономикалық дамыған аймақтағы зияткерлік әлеуетті дамыту үшін әр түрлі стратегиялық қадамдар жасалуы тиіс. Сол себепті, зияткерлік әлеуетті дамыту жолында әр аймақтың ерекшелігі ескеріліп, сәйкесінше даму бағыттары қабылданса, болашақта оң әсер береді. Жалпы, аймақтың дамуын зияткерлік әлеуеттің дамуынан байқауға болады. Аймақта өмір сүретін тұрғылықты халықтың зияткерлік әлеуеті жоғары болса, ол аймақ экономикалық даму бойынша ешқашан артта қалмайды. Тұрғылықты халықтың әлеуетін анықтау үшін оған әсер ететін факторларға көз жүгірту керек. Яғни, зерттеліп отырған мәселеге байланысты, мақаланың мақсаты - Қазақстан аймақтарындағы зияткерлік әлеуетке әсер ететін факторларды анықтау және талдау жүргізу.

\section{Әдеби шолу}

Аймақтардағы зияткерлік әлеуетке әсер ететін факторлар туралы шетелдік және отандық әдебиеттерде мәліметтер жеткілікті. В. Цомартованың [1] аймақтағы зияткерлікті әлеуетті мониторингілеу жүргізгенде, зияткерлік әлеуетке әсер ететін екі маңызды факторды атайды, олар: білім беру әлеуетінің өзгеру коэффициенті және ғылыми потенциалдың өзгеру коэффициенті.

Көптеген әлеуметтанушылар мен экономистер бірдей ұстанымға ие: М.Н.Руткевич, В.К. Левашов [2] және Ю.П. Лежина [3] т.б. олардың ойынша, зияткерлік әлеуеттің дамуына ғылым мен білім даму деңгейі әсерін тигізеді.

H. Mishchuk, I. Roshchyk, J. Sułkowska және S.Vojtovic [4] зерттеулерінде зияткерлік әлеуетті бағалауда жоғары білімі бар 15-74 жастағы халық, жоғары білімі бар 15-74 жас аралығындағы экономикалық белсенді халық, жоғары білімі бар 15-74 жас аралығындағы жұмыспен қамтылған халық, жоғары білімі бар менеджерлер, мамандар, техникалық және қауымдастырылған мамандар, жоғары білімі бар АКТ саласында жалданған мамандар; жалпы ғылыми-зерттеу қызметкерлері мен зерттеушілері; зерттеушілер қатысты көрсеткіштерді қолданады. Яғни, зияткерлік әлеует дамуына білім беру жүйесінің маңыздығын атайды [5].

Американдық экономист J. Kendrick [6,7] пайымдауынша, адамның ментальды дамуына субъектінің шығындары әсер етеді. Туылған сәтінен бастап, өскенше дейінгі шығыстар, білім саласында жұмсаған шығыстары, денсаулық саласында жұмсаған шығыстары, ой-өрісін кеңейтуге бағытталған, мәдени-рухани дамуға бағытталған және т.б. шығыстар әсері туралы зерттеген.

Отандық ғалымдардың зерттеулерінде адам капиталы мен зияткерлік капитал, зияткерлік әлеует бір-бірімен тығыз сабақтасады. Н.К. Нурланова [8] зерттеулерінде, аймақтардың дамуын аймақтардағы адам ресурстарының зияткерлік қабілеттіліктерін ынталандыру арқылы инновациялық дамудың халықаралық рейтингтерінде салыстырмалы түрде жоғары орын алуға болатындығы айтылады. М.К. Мельдаханова [9] және С.А. Калиева [10] адамның зияткерлік қабілетін тиімсіз қолдану экономикадағы еңбек өнімділігін төмендетуге әкеліп, адами ресурстың бәсеке қабілеттілігін төмендетеді деп пайымдайды.

Зияткерлік әлеуеттің маңыздылығы туралы Р.К. Сагиева [11], Р.М. Рузанов [12], А.Жупарова [11] зерттеулер жүргізген. Адамның зияткерлік капиталы адамның мотивациясы, білімі, дағдылары, өмірлік күші, денсаулығы, біліктілігі, ұзақ уақыт бойы пайдаланылатын және өзіне табыс әкелетін, сонымен қатар экономиканың дамуына, оның ақпараттандырылуына, экономикалық өсуіне жағымды әсер ететін, жаңа технологиялық тәртіпке көшуге ықпал ететін, инновацияның қайнар көзі және инновациялық дамудың қозғалтқышы болып табылатын адамның туа біткен және инвестициялар арқылы алынған қабілеттері ретінде қарастырады.

\section{Әдіснама}

Зерттеудің теориялық және әдіснамалық негізі зияткерлік әлеуеттің қалыптасуы мен оған әсер ететін факторларды қарастыратын мәселелер болып табылады. Зерттеу барысында бақылау және салыстыру, жүйелік талдау, синтез және логикалық әдістер қолданылды. Зияткерлік әлеуеттің деңгейін анықтаумен айналысқан шетелдік және отандық авторлардың зерттеулерінен Қазақстан аймақ- 
тарындағы зияткерлік әлеуетке әсер ететін факторларды жүйелесек, олар: білім, ғылым, мәдени факторлар. Бұдан басқа, зияткерлік әлеуеттің нәтижесі ретінде инновациялық факторды қосу қажеттігін айта өткен жөн. Себебі, инновациялық технология - адамның зияткерлік қабілетінен пайда болған нәтиже. Сол себепті, талдау барысында инновациялық факторларды қарастыру аймақтар бойынша зияткерлік әлеуеттің дамуы деңгейін анықтауда ықпалын тигізеді.

Талдау барысында ҚР статистика комитетінің мәліметтері қолданылады. Зияткерлік әлеует факторлары анықталып, 2009 және 2019 жылдардағы статистикалық мәліметтер салыстырылып, тұжырымдамалар анықталады. Статистикалық мәліметтер аймақтар бойынша зияткерлік әлеуеттің дамуына әсер ететін факторлардың салыстырмалы әсерін көрсетеді. Зияткерлік әлеуеттің дамуы бойынша әлсіз және мықты аймақтар анықталады.

\section{Зерттеу нәтижелерін талқылау}

Макро деңгейде халықтың зияткерлік әлеуеті елдің әлеуметтік-экономикалық дамуының жалпы деңгейінде (жалпы өнімнің көлемі мен құрылымы, елдің инвестициялық тартымдылығы және т.б.) көрініс табады. Ал аймақтар деңгейінде аймақтардағы білімғылым жүйесінің, инновацияның даму жағдайына және мәдени-рухани жағдайына байланысты болады. Сол себепті елдегі зияткерлік әлеуетті сипаттайтын факторларға білім мен ғылымның даму жағдайы, инновация дамуы және мәдениеттіліктің даму деңгейі жатады.

Әрбір фактор әр түрлі көрсеткіштердің жиынтығы болып табылады.

1) Білім - білімге негізделген экономика дамуының іргелі факторы. Ол - ғылымға негізделген экономиканың негізгі қозғаушы күші және ресурсы, өсу көзі, сонымен қатар аймақтың материалдық және рухани дамуының негізі болып табылады. ҚР-дағы ғылым мен білім беру салалалар деңгейінің төмендеуі қызметкерлердің сапалық құрамының нашарлауымен, жастар ағымының қысқаруымен, мамандардың шетелге кетуімен, ғылым докторларының қартаюымен, ғылым мен білімді қаржыландыру аздығымен және т. б. сипатталатынын мойындау керек.

Қазақстан 2019 жылы білім деңгейі индексі бойынша әлем елдерінің рейтингісінде 0,817 индексімен 38-орында, ал 2014 жылы 0,798-ді құрады. Қазақстан осы рейтинг бойынша Венгрия, Франция, Италия, Португалия және т. б. бірқатар дамыған және дамушы елдерді басып озады (сурет 1). Білім индексі жас және ересек жастағы тұрғылықты халықтың сауаттылығын сипаттайды. Ал, сауаттылық деңгейі адамдардың оқу және жаза алу қабілеттіліктерін сипаттайды. Білім - адамдардың өмір сүру сапасын көрсететін индикатордың бір құрамдас бөлігі. Сурет 1 мәліметтеріне сай, Қазақстан халқының көпшілігі сауатты болып отыр, Қырғызсан, Армения, Италия, Украина және басқа мемлекеттерге қарағанда қазақстандықтардың 98\% жуығы жазуға және оқуға қабілетті.

Аймақтардың әлеуметтік-экономикалық дамуына аймақтағы ЖОО беретін білімнің әсері туралы көптеген экономист ғалымдар зерттеулерінде жан басына шаққандағы ЖІӨ көрсеткіштері мен жоғары білімі бар халықтың үлесі арасында оң, бірақ өте күшті тәуелділік бар екендігін атайды [7]. Халықтың жоғары білім деңгейі мен өңірлер бойынша халықтың табыс деңгейі арасында айтарлықтай оң байланыс байқалады. Себебі, ЖОО мамандық тәмәмдаған тұлға белгілі бір зияткерлік білімге ие болып, өз білімін тәжірибеде қолданып, материалдық пайда көреді, ол оның өмір сапасын арттырады. Білім беру әлеуетінің мәні жоғары кәсіптік білім алғаннан кейін жас ұрпақтың кәсіби дайындық деңгейін сипаттайды.

Кесте 1 бойынша ҚР ЖОО жағдай 2000 жылдан 2019 жылға дейін студенттер санының оң динамикасы байқалады. Олардың аумақ пен өңірлердің зияткерлік әлеуетінің тікелей сипаттамаларының бірі болып табылатын халық құрамындағы үлесі 2000-2019 жылдар аралығында Қазақстан бойынша ұлғайды. Кесте 1 сәйкес 2000 жылы Қазақстанда 440715 студент болса, 2005 жылы 775 762, 2019 жылы 604345 студент құрап отыр. Ең көп тіркелген студенттер саны 2005 жыл. Тәуелсіздік алынған соң 15 жылда мемлекетте сан алуан түрлі ЖОО ашылып, студенттер саны ұлғайып, халықтың зияткерлік деңгейі көтерілді. Оның басты себебі, 2005 жылы Елбасының бастауымен «Болашақ» бағдарламасы енгізілді. Жас жеткіншектер арасында шетелден білім алуға ұмтылатындар саны артты. Халықтың білім деңгейін көтеретін мемлекеттік бағдарламалар енгізіліп, гранттар саны ұлғайды. 


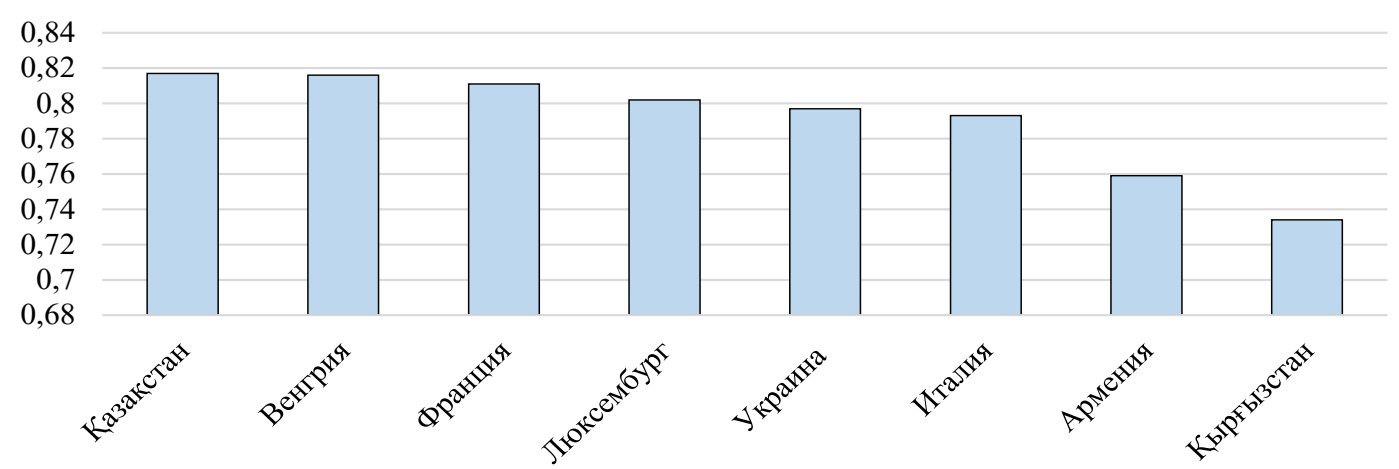

Сурет 1 - Білім деңгейінің индексі бойынша әлем елдерінің рейтингісі

Figure 1 - Ranking of the countries of the world according to the education level index

Ескерту - Авторлармен құрастырылған

Кесте 1 - Қазақстан аймақтарын білім әлеуеті тұрғысынан рейтингтік бағалау

Table 1 - Rating of the regions of Kazakhstan in terms of educational potential

\begin{tabular}{|c|c|c|c|c|c|c|c|c|c|c|c|c|}
\hline \multirow[b]{2}{*}{ Аймақ } & \multicolumn{4}{|c|}{$\begin{array}{c}\text { Мектеп біріуші } \\
\text { оқушылардың } 10000 \text { адамға } \\
\text { шаққандағы саны }\end{array}$} & \multicolumn{4}{|c|}{$\begin{array}{c}\text { ЖОО түскен студенттер } \\
10000 \text { адамға шаққандағы } \\
\text { саны } \\
\end{array}$} & \multicolumn{4}{|c|}{$\begin{array}{c}\text { ЖОО бітірген студенттер } \\
\text { саны, } 10000 \text { адамға } \\
\text { шаққандағы }\end{array}$} \\
\hline & 2009 & 罵 & 2019 & 焉 & 2009 & 思 & 2019 & 壱 & 2009 & 思 & 2019 & 焉 \\
\hline $\begin{array}{l}\text { Қазақстан } \\
\text { Республикасы }\end{array}$ & 14,2976 & - & 11,7204 & - & 18,1605 & - & 16,3494 & - & 17,6016 & - & 14,2435 & - \\
\hline Ақмола обл & 0,6083 & 11 & 0,4281 & 13 & 0,5237 & 11 & 0,2919 & 15 & 0,6877 & 9 & 0,4139 & 11 \\
\hline Ақтөбе обл & 0,6614 & 8 & 0,5543 & 9 & 0,7575 & 9 & 0,7796 & 6 & 0,6086 & 11 & 0,588 & 8 \\
\hline Алматы обл. & 1,5217 & 2 & 1,3296 & 2 & 0,312 & 15 & 0,3125 & 13 & 0,2862 & 17 & 0,2235 & 14 \\
\hline Атырау м. & 0,4426 & 15 & 0,4254 & 14 & 0,4074 & 13 & 0,3507 & 11 & 0,531 & 12 & 0,3539 & 12 \\
\hline БҚО & 0,641 & 9 & 0,4281 & 13 & 0,8146 & 8 & 0,7721 & 7 & 0,7293 & 8 & 0,9805 & 5 \\
\hline Жамбыл обл. & 0,9588 & 5 & 0,7178 & 5 & 0,9767 & 6 & 0,5513 & 8 & 0,8377 & 7 & 0,6458 & 7 \\
\hline Қарағанды обл. & 0,9625 & 4 & 0,7156 & 6 & 1,9467 & 2 & 1,1561 & 4 & 1,5537 & 3 & 1,2552 & 3 \\
\hline Қостанай обл. & 0,6087 & 10 & 0,459 & 12 & 0,8354 & 7 & 0,4955 & 10 & 0,8462 & 6 & 0,5526 & 9 \\
\hline Қызылорда обл. & 0,6931 & 7 & 0,5605 & 8 & 0,453 & 12 & 0,2162 & 17 & 0,4534 & 13 & 0,3058 & 13 \\
\hline Маңғыстау обл. & 0,4199 & 16 & 0,5219 & 11 & 0,2619 & 17 & 0,3091 & 14 & 0,3111 & 16 & 0,0901 & 17 \\
\hline Павлодар обл. & 0,5639 & 13 & 0,36 & 15 & 0,7033 & 10 & 0,5469 & 9 & 0,6192 & 10 & 0,4426 & 10 \\
\hline СҚО & 0,6007 & 12 & 0,3109 & 16 & 0,2881 & 16 & 0,2393 & 16 & 0,3365 & 15 & 0,1896 & 16 \\
\hline Түркістан обл. & 2,6244 & 1 & 1,8928 & 1 & 0,3783 & 14 & 0,3322 & 12 & 0,3446 & 14 & 0,1915 & 15 \\
\hline ШҚО & 1,2381 & 3 & 0,814 & 4 & 1,4767 & 4 & 0,8513 & 5 & 1,2163 & 4 & 0,8248 & 6 \\
\hline Нұр-Сұлтан қ. & 0,3007 & 17 & 0,5419 & 10 & 1,1285 & 5 & 1,6012 & 3 & 1,0255 & 5 & 1,1904 & 4 \\
\hline Алматы қ. & 0,9166 & 6 & 0,9587 & 3 & 5,3148 & 1 & 4,8989 & 1 & 5,5281 & 1 & 3,0886 & 1 \\
\hline Шымкент қ. & 0,5352 & 14 & 0,7018 & 7 & 1,5819 & 3 & 2,6446 & 2 & 1,6865 & 2 & 2,9067 & 2 \\
\hline
\end{tabular}

Ескерту - Авторлармен құрастырылған. 
Білім іздеген жас баланың алдында үлкен мүмкіндіктер ашылды. Дегенмен, 2005 жылға қарағанда 2019 жылы студенттер саны 170 мыңға кем. Соңғы 10-15 жыл ішінде ЖОО берілетін білім саны төмендеп, дайын мамандар алдында жұмысқа тұру стандарттары көтеріліп, студенттер саны азая түсуде. Аймақтар бойынша ең көп ЖОО шоғырланған Алматы мен Нұр-сұлтан қалалары, сәйкесінше, басқа аймақтарға қарағанда студенттер саны да жоғары. Алматыда 29, Нұр-Сұлтанда 9, Шымкентте 8, Қарағандыда 6 университет орналасқан. Осы аймақтар мемлекеттің экономикалық дамуында маңызды орын алады. Сондықтан, республикалық маңызды қалаларда білім алған жастар, оку орнын бітірген қалаларда жақсы өмір сүру мақсатымен жұмысқа орналасып, қалып қалады. Үлкен қалаларда білімді де, білікті мамандарға сұраныс әрдайым болады. Алматыдан кейін екінші орында Шымкент қаласы студенттер саны бойынша жоғары көрсеткіш көрсетеді. Себебі, біріншіден, бұл аймақта халық тығыздығы жоғары; екіншіден, тұрмыс-тіршілік деңгейі төмен; үшіншіден, білім алу арзанға түседі. Студенттер саны бойынша келесі аймақ Қарағанды облысы тұр. Қарағанды қаласында Алматыдағыдай көпсалалы ірі Е.А.Букетов университеті мен техникалық, медициналық университеттері орналасқан. Білім беру деңгейі Алматы университеттерінен кем түспейді. Яғни, зияткерлік әлеуеттегі білім беру әлеуеті бойынша, студенттер саны жоғары болған аймақтардың даму деңгейі де жоғары болып отыр. Сәйкесінше, дамыған аймақтарда жұмыс орнымен қамтылған зияткерлік жастар деңгейі де жоғары болады.

Қорытындыласақ, аймақтағы зияткерлік әлеуеттің деңгейіне тұрғылықты халықтың білім деңгейі тура әсерін береді. Оған дәлел, шетелдік ғалымдардың зерттеулерінде зияткерлік әлеуеттің қалыптасуының ең маңызды бөлшегі білім беру жүйесіне тиесілі. Сол себепті, аймақтағы тұрғылықты халық эрудитті, ментальды ой-өрісі дамыған болып саналса, аймақтың да экономикалық дамуы өседі.

2) Ғылыми әлеует - ғылыми жаңалықтар, өнертабыстар мен техникалық жаңалықтар үшін, сондай-ақ ғылым мен оның қосымшалары ұсынған ұлттық және ұлтаралық мәселелерді шешу үшін елдің қол жетімді ресурстарының жиынтығы [8]. Ғылым - бұл адамның іс-әрекетінің нақты саласы, онда материалдық әлемнің объектілері туралы жаңа білім алу, оларды адамдардың практикалық ic-әрекетінде қолдану мақсатында қоғам дамуының объективті заңдылықтарын білу түрінде зияткерлік өнімдер жасалады. Аймақтағы ғылым деңгейін сипаттауда аймақтағы ЖОО оқитын докторанттар/ аспиранттар санын, ғылыми кадрлар санын және ғылымға деген ішкі шығындар көлемін алдық. Оны алу салдары болып, шетелдік ғалымдардың зерттеулері негіз болады. Шетел әдебиеттерінде, зияткерлік әлеуетті қалыптастыруда маңызды орын алатын құрамдас бөлік ғылым саласы болып табылады. Қазақстан бойынша кесте 22000 жылдан 2019 жылға дейін докторантураға қабылдау 81-ден 1775 адамға дейін өскенін байқаймыз. Бітіру 78-ден 905 адамға дейін өсті; осы көрсеткіш бойынша аспирантураның жұмыс сапасын жақсарту үрдісі бар деп бағалауға болады; 2000 жылдан 2019 жылға дейін ғылыми кадрларды 14 759-дан 21843 адамға дейін арттырудың жалпы үрдісі байқалды. Сонымен қатар, бұл үрдіс зерттеушілерге де, техниктер мен көмекші қызметкерлерге де тән. Егер соңғы бес жылды салыстыратын болсақ, 25 793-тен 21 843-ке дейін кері үрдіс байқалып, көрсеткіштер төмендейді. Ал соңғы 10 жылды қарастырсақ, ғылыми зерттеулер мен әзірлемелерді орындаушы қызметкерлердің саны 2010 жылы Алматы қ. 8178, 2019 жылы 8859 адамға көбейді, НұрСұлтан қ. 2010 жылы 1531 болса, 2019 жылы 3027 болып 2 есе ұлғайды. Оны соңғы жылдары көптеген қаржылай, ғылыми, мәдени сфералардың Алматы қ. Нұр-Сұлтан қаласына бағыт бұрғандығымен түсіндіруге болады. Шығыс Қазақстан облысы бойынша 2010 жылы ғылыми зерттеулер мен әзірлемелерді орындаушы қызметкерлердің саны 1852 адам болса, 2019 жылы 2161 құрап отыр. Оған себеп, негізгі түсті металды өңдеу және өзге ауыр металдардың шикізат көздері осы аймақта орналасқан. Соңғы жылдары шикізаттан дайын өнім өндіруге көп мән беруде. Дайын өндірілген өнімді экспортқа шығаруға бағытталған мемлекеттік бағдарламалар жүзеге асырылып жатыр. Дегенмен, дайын өнімді өндіру оңай үдеріс емес. Өнімді өндіру үдерісіне дейін, ғылыми, инновациялық, ұйымдастырушылық зерттеулері жүргізіледі. Соның салдарынан, ШҚО-нда ғылыми зерттеулер мен әзірлемелерді орындаушы қызметкерлердің саны артып келеді. Тура осындай себеп Қарағанды облысындағы ғылыми қызметкерлер саны мен докторанттар санының 2010 жылы 875-тен 2019 жылға 1259 артуы, ал докторанттар санының 31-ден 2019 жылы 486 өсуін түсіндіруге болады. 
Кесте 2 - Аймақтар бойынша ғылыми зерттеулер мен әзірлемелерді орындаушы қызметкерлер мен докторанттар саны

Table 2 - The number of employees and doctoral students performing research and development in the regions

\begin{tabular}{|c|c|c|c|c|c|c|c|c|}
\hline \multirow{2}{*}{ Аймақ } & \multicolumn{4}{|c|}{$\begin{array}{c}\text { Ғылыми зерттеулер мен } \\
\text { әзірлемелерді орындаушы } \\
\text { қызметкерлердің саны, } 1000 \\
\text { адамға шаққандағы }\end{array}$} & \multicolumn{4}{|c|}{$\begin{array}{c}\text { Докторанттар саны, } 1000 \text { адамға } \\
\text { шаққандағы }\end{array}$} \\
\hline & 2010 & 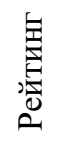 & 2019 & ص & 2010 & 志 & 2019 & 息 \\
\hline Ақмола & 0,615 & 6 & 0,789 & 6 & 0,01 & 9 & 0,045 & 12 \\
\hline Ақтөбе & 0,195 & 13 & 0,42 & 13 & - & - & 0,07 & 9 \\
\hline Алматы & 0,759 & 5 & 0,935 & 5 & 0,003 & 13 & 0,126 & 6 \\
\hline Атырау & 0,582 & 7 & 0,471 & 12 & 0,004 & 12 & - & - \\
\hline Батыс Қазақстан & 0,459 & 9 & 0,534 & 11 & 0,007 & 10 & 0,022 & 15 \\
\hline Жамбыл & 0,344 & 10 & 0,308 & 14 & 0,015 & 8 & 0,046 & 11 \\
\hline Қарағанды & 0,875 & 4 & 1,259 & 4 & 0,031 & 5 & 0,486 & 3 \\
\hline Қостанай & 0,324 & 12 & 0,592 & 10 & 0,005 & 11 & 0,062 & 10 \\
\hline Қызылорда & 0,098 & 17 & 0,183 & 15 & - & - & 0,045 & 12 \\
\hline Маңғыстау & 0,474 & 8 & 0,689 & 8 & - & - & 0,034 & 14 \\
\hline Павлодар & 0,187 & 14 & 0,621 & 9 & 0,054 & 3 & 0,11 & 7 \\
\hline Солтүстік Қазақстан & 0,106 & 15 & 0,092 & 17 & - & - & 0,044 & 13 \\
\hline Түркістан & 0,102 & 16 & 0,182 & 16 & 0,023 & 6 & 0,077 & 8 \\
\hline Шығыс Қазақстан & 1,852 & 2 & 2,161 & 3 & 0,049 & 4 & 0,304 & 4 \\
\hline Нұр-Сұлтан қаласы & 1,531 & 3 & 3,027 & 2 & 0,198 & 2 & 1,473 & 2 \\
\hline Алматы қаласы & 8,178 & 1 & 8,859 & 1 & 0,539 & 1 & 3,245 & 1 \\
\hline Шымкент қаласы & 0,34 & 11 & 0,721 & 7 & 0,022 & 7 & 0,174 & 5 \\
\hline Қазақстан Республика & 17,021 & & 21,843 & & 0,96 & & 6,363 & \\
\hline
\end{tabular}

Ескерту - Авторлармен құрастырылған.

Бұдан басқа, Алматы қ., НұрСұлтан қ., ШҚО облысында, Қарағанды облыстарында ғылыммен айналысуға қажетті ең көп инфрақұрылым, зерттеу мекемелері шоғырланған.

Өзінің зияткерлік әлеуетін арттыратын аймақтың маңызды сипаттамасы - бұл экономикаға инвестициялар көлемі, дәлірек айтсақ, олардың зерттеу мен дамуға бағытталған бөлігі. Бұл көлем, сайып келгенде, негізгі құралдарға салынған инвестициялардың көлеміне сәйкес келуі мүмкін немесе одан да асып кетуі мүмкін. Мәселен, соңғы 10 жылда ғылымға арналған бюджет шығыстары айтарлықтай өсті. Алайда, егер оларды дол-лармен есептесек, қаржыландырудың төмендегенін көруге болады.
Қазіргі уақытта ғылым саласында көптеген проблемалар бар, олардың бастысы:

ғылыми зерттеулер мен әзірлемелердің барлық секторларындағы ұйымдар қазіргі заманғы материалдық-техникалық базамен төмен қамтамасыз етілуі;

- барлық санаттағы зерттеушілерге еңбекақы төлеудің төмен деңгейі, өзінің ғылыми әлеуетін іске асыру және мансаптық өсуді құру перспективаларының болмауы және т.б., бұл оның тиімділігін айтарлықтай төмендетеді.

Қорытындыласақ, аймақтағы зияткерлік әлеуеттің қалыптасына ғылымның дамуы жақсы әсерін береді. Ғылымның дамуы зиткерлік дамуы жоғары тұлғалардың көмегімен жүзеге асады және оның нәтижесі 


\section{REGIONAL ECONOMY AND TERRITORIAL DEVELOPMENT}

ретінде инновациялық өнім беріледі. Қазақстан бойынша, ғылымның дамуы Алматы қ., Нұр-Сұлтан қ., ШҚО мен Қарағанды облыстарында қарқынды темппен дамуын көре аламыз. Оған басты себеп болып, Алматы мен Нұр-Сұлтан қалалары - республикалық маңызы бар қалалар. Олар мемлекеттің негізгі экономикалық, қаржылай, мәдени, ғылыми даму орталығы болып отыр. Ал ШҚО мен Қарағанды облыстары мемлекеттегі шикізат өнімін өндіретін алдыңғы қатарлы аймақтарға жатады. Шикізат шығаратын зауыттар дайын өнімді шығаруға бағытталған зерттеу жұмыстарына жылда үлкен қаражаттар бөлінеді, ал олар аймақта ғылымның дамуына алып келеді деп тұжырымдауға болады.

3) Инновациялық әлеует - өңірдің зияткерлік әлеуетінің маңызды құрамдас бөлігі. Қазіргі уақытта дамыған елдерде жалпы ішкі өнімнің 70-85\% өсуі өндіріс пен басқарудың инновациялық технологияларында енгізілген жаңа білімнің үлесіне келеді [9]. Инновациялық өнімді өндіруге бағытталған білім - қоғамда негізгі капиталға айналды. Инновация ғасыры жаңа инновациялық қоғам ғасырының пайда болуына себепші болды. Жаңа инновациялық өркениет қалыптасу барысында. Инновациялық өнім адамның өмір сүруін жан-жақты жеңілдетеді. Инновациялық даму мемлекеттердің өзара бәсекеге түсуінде маңызды фактор болып отыр. Инновация жайлы ой-толғаулар шексіз. Ұлт- тық инновациялық жүйенің сапалық сипаттамасы - инновациялық әлеует ғылыми білімді өнімдердің, технологиялар мен қызметтердің жаңа түрлеріне айналдыру. Яғни, белгілі бір үрдіске зияткерлік капитал салынғаннан пайда болатын нәтиже инновациялық өнімді береді.

Инновациялық белсенділік - бұл ұлттық экономиканың жағдайы мен бәсекеге қабілеттілігінің икемді көрсеткіші. Бұл белсенділіктің төмендеуі нарықтардағы позициялардың жоғалуын, өндірістік куаттардың қартаюын, инвестициялық, технологиялық және экономикалық дағдарыстардың өсуін білдіреді. Қазақстандағы инновациялық жағдайды қарастырып, оның аймақтардың дамуындағы әсерін қарастырсақ, кесте 3 сәйкес, 2019 жылы инновациялық белсенділік Нұр-Сұлтан қ., ШҚО, Қарағанды облысы, Жамбыл облыстары ерекшеленіп отыр. Ал инновациялық белсенділік төмен аймақтарға Маңғыстау мен Атырау облыстары және Шымкент қ. жатады.

Дүниежүзілік экономикалық форумның бағалауы бойынша Қазақстан инновациялық дамуы артта қалған елдер тобына жатады. Мемлекетте инновациялық өнімді шығару мен қолдау қалыптасу сатысында тұр. Инновацияның дамымауы мемлекеттің экономикалық дамуын тежеуіші ретінде болып отыр. 2018 жылғы мәліметтерге сай, әлемдегі ҒЗТКЖ-ға арналған шығыстар бойынша Қазақстан төмен деңгейді көрсетеді (сурет 2).

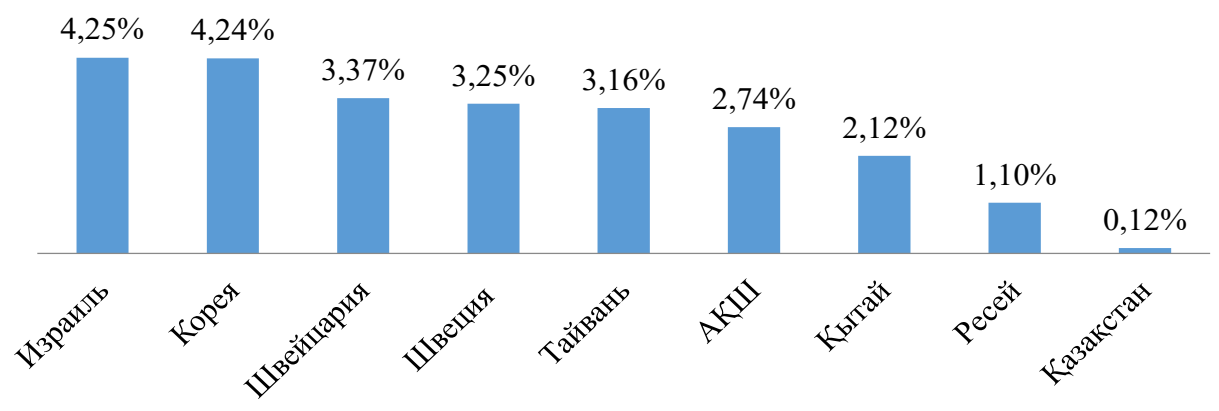

Сурет 2 - Әлемдегі ҒЗТКЖ -ға арналған шығыстар, ЖІӨ - ден \%-бен, 2018 жыл

Figure 2 - Spending on R\&D in the world, in \% of GDP, 2018

Ескерту - Авторлармен құрастырылған.

Өзінің макроэкономикалық көрсеткіш-тері бойынша Қазақстан орташа табыс деңгейі бар елдерге жатады, бірақ экономикада білімді қолдану деңгейін сипаттайтын индекс бойынша елді табысы төмен Кения және Моңғолия сияқты елдермен салыстыруға болады. Дегенмен, соңғы жылдары мемлекет тарапынан ҒЗТКЖ-ға арналған шығыстар көлемін 4-5 есе ұлғайтуға бағытталған жұмыстар жүруде. Бірақ, ҒЗТКЖ жаппай қаржыландырудың да кері әсері болуы мүмкіндігін ұмытпаған жөн. Мемлекеттегі 
ҒЗТКЖ бағытталған қаржыландыру көздері артқанымен, болашақта ешқандай нәтижесе бермеген шетелдік тәжірибеде мысалдар бар. Бұл жерде басты назарды басқаруға жұмсау дұрыс болуы мүмкін.

Инновацияның тиімділігі елдегі жалпы экономикалық жағдайға және мемлекеттік ғылыми-техникалық стратегияға, толыққанды ресурстық қамтамасыз етуге, нарықтық жағдайға, кәсіби кадрлардың болуына және тиімді басқаруға байланысты.

4) Зияткерлік әлеуетті дамытудың тағы бір маңызды факторы мәдени әлеует болып табылады, бұл индивидумның рухани деңгейін арттыру мақсатында қоғамның сұраныстарына сәйкес келу қабілеті деп түсініледі. Мәдени әлеует қоғамның моральдық жағдайының, жалпы және кәсіби білімнің сапалық және сандық сипаттамасы ретінде түсініледі. Мәдени әлеует - адам мен қоғамның рухани дамуына бағытталған қызмет. Бұл әрекеттің нәтижесі - рухани мәдениет деп аталатын жаңа идеялар, білім, рухани құндылықтар. Демек, мәдени мұра іргелі мәнге ие және аймақтың рухани және зияткерлік әлеуетінің негізін құрайды. Осылайша, рухани мәдениет зияткерлік әлеуеттің өнімі болып табылады. Ол - адамның жеке басын оятатын, қолдайтын және дамытатын рухани мәдениет.

Жалпы мәдени әлеуеттің көрсеткіштері оң үрдіске ие, бірақ зияткерлік әлеуетті толыққанды пайдалану және дамыту үшін мәдени компонентті күшейту керек. Бұл үрдісті болашақ жастар мен мектеп білімгерлерін театрларға, мұражайларға баруын ынталандыру арқылы іске асырған жөн (кесте 4) [11]. Қазақстандағы театрлар мен мұражайларға қызығушылық білдіретін тұрғылықты халықтың көлемі 2019 жылы 3 млн адамға жуық болды. Ал мұражайларға келушілердің саны 2019 жылы 6,8 млн адам қамтыды. Тәуелсіздік алғаннан бері 1995 жыл мен 2019 жылды салыстыратын болсақ, қазақстандықтардың мәдени дамуға деген қызығушылығы артқанын көре аламыз. Оған басты себеп ретінде, ғаламшарда болып жатқан жаһандану мен интеграция үрдістері болып табылады. Адамдар рухани мәдениетті тек мемлекет аясында танып біле ғана қоймай, шетелдік мәдениетке, тарихқа, фольклорға және т.б. мәдениеттілікті арттыратын құбылыстарға қызығушылық білдіреді.

Кесте 3 - Қазақстан Республикасы мәдениетінің негізгі көрсеткіштері

Table 3 - The main indicators of the culture of the Republic of Kazakhstan

\begin{tabular}{|l|r|r|r|r|r|r|r|}
\hline \multicolumn{1}{|c|}{$\begin{array}{l}\text { Мәдени саласының негізгі } \\
\text { көрсеткіштері }\end{array}$} & \multicolumn{1}{|c|}{1995} & \multicolumn{1}{c|}{2000} & 2005 & 2010 & 2015 & 2018 & 2019 \\
\hline Кәсіби театрлар саны & 45 & 49 & 51 & 59 & 64 & 68 & 65 \\
\hline $\begin{array}{l}\text { Театр көрермендерінің саны, мың } \\
\text { адам }\end{array}$ & 2008,6 & 1376,5 & 1795,0 & 2010,6 & 2249,1 & 2833,6 & 2942,1 \\
\hline Мұражайлар саны & 87 & 147 & 187 & 205 & 234 & 245 & 250 \\
\hline $\begin{array}{l}\text { Мұражайларға келушілер саны, } \\
\text { мың адам }\end{array}$ & 2500 & 3181,6 & 3525,4 & 4262,7 & 5719,9 & 6716,0 & 6829,3 \\
\hline
\end{tabular}

Ескертпе -Авторлармен құрастырылған.

Сонымен, мәдениет сөзсіз экономикалық жетістікке белгілі бір әсер етеді деп қорытынды жасауға болады. Алайда мәдениет саласына өзгеріске ұшыраған діни, тарихи, географиялық және басқа факторлар әсер етеді. Мәдениеттің өзі де өзгеріске ұшырайды. Қазақстан аймақтарындағы халықтың тұрмыстіршілігінің деңгейі, табыс деңгейі, денсаулық жүйесінің жұмысы, мәдени мұражайлар, ескерткіштер, концерттер, көрмелер және т.б. жағдайлар әр түрлі деңгейде дамып отыр. Адамның мәдени-рухани дамуы үшін адамға демалыс орындарының, демалу саябақтарының, діни табыну орындарының да болуы қосалқы әсерін тигізеді. Яғни, Қазақстанның аймақтарындағы мәдени әлеуетті бағалау пәнаралық тәсіл арқылы талдауды қажет етеді.
Iрі қалаларда әдеби, рухани, мәдени шаралар жиі болады, соған орай Қазақстанның экономикалық маңызды ірі орталықтарында, облыс орталықтарында, республикалық маңызы бар қалаларда мәдени, рухани, әдеби шаралар жиі болып отырады. Сәйкесінше, бұл аймақта өмір сүретін халық ұйымдастырылған мәдени шараларға қол жетімді болғандықтан, бара алады. Оның ішінде, музей, театр, концерт және т.б. бар. Бұндай шараларға бару үшін тұрғылықты халықтың табыс деңгейі де сәйкес болуы тиіс Ал экономикалық тұрғыдан төмен аймақтарда ондай мүмкіншілік бола бермейді. Ол аймақтарда табыс деңгейі төмен, тұрғылықты халық сауықтыру шаралары емес, күн көрісті ойлайды. Мәдени әлеует адамның 
зияткерлік әлеуетіне қосалқы әсер еткенімен, ол оның ой-өрісін жан-жақты дамытуға көмек етеді. Сондықтан, мәдени әлеуетті анықтау салыстырмалы шама болып саналады.

Соңғы уақытқа дейін экономистердің көпшілігі экономикалық құбылыстар мен процестерді талдау кезінде мәдени факторды елемеді. Көп жағдайда бұл “мәдениет” ұғымын нақты анықтаудағы қиындықтарға байланысты болды. Алайда, көптеген зерттеушілер жеке этностарға, конфессиялар мен халық топтарына тән дәстүрлер мен әдеттер олардың экономикалық жетістіктеріне айтарлықтай әсер етеді деп санайды.

\section{Қорытынды}

Зияткерлік әлеуетке тура және жанама әсер ететін факторлар көпшілік. Ел аймақтарының дамуына зияткерлік әлеуеттің әсері әр түрлі факторлармен сипатталады. Шетелдік әдебиеттерге сай, зияткерлік әлеуетті қалыптастыратын басты факторлар болып білім мен ғылым болып табылады деп көрсетіледі. Кей шетелдік ғалымдардың пайымдауынша білім мен ғылымнан басқа, аймақтағы дамуды көрсететін зияткерлік әлеуеттің құрамдас бөлігіне инновациялық үрдіс жатады. Зияткерлік әлеуеттің аймақтағы дамуына мәдени факторда қосалқы әсерін тигізеді. Яғни, аймақтардағы зияткерлік әлеуеттің құрылымдық бөлшектеріне білім және ғылым, инновация және мәдени факторлары жататындығы анықталды. Қазақстан аймақтарының дамуына зияткерлік әлеует әсерін анықтау барысында келесідей тұжырымдамалар жасалынды:

- аймақтағы тұрғылықты халық эрудитті, ментальды ой-өрісі дамыған болып саналса, аймақтың да экономикалық дамуы өседі;

- ғылымның бәсеңдеуі зерттеулер мен әзірлемелердің барлық секторларындағы ұйымдардағы материалдық-техникалық базаның ескіруі мен қаржыландырудың жетіспеушілігімен сипатталады;

- инновацияның тиімділігі мемлекеттегі экономикалық жағдайға, мемлекеттік ғылыми-техникалық стратегиясына, толыққанды ресурстық қамтамасыз етілуіне, нарықтық жағдайға, кәсіби кадрлардың болуына және тиімді басқаруға байланысты;

- зияткерлік әлеуеттің жоғарылауына мәдени фактор жанама септігін тигізеді. Экономикалық құбылыстар мен процестерді талдау кезінде мәдени фактордың әсері бар екендігіне экономист ғалымдар арасында көз жетті.
Қазақстан аймақтары бойынша зияткерлік әлеуеттің құрамдас бөліктеріне талдау жүргізілді. Білім және ғылымның дамуы бойынша Алматы қ., Нұр-Сұлтан қ., Шымкент қ. алдыңғы қатарда тұр. Себебі, бұл қалаларда мемлекеттегі басты ЖОО, ғылыми-зерттеу мекемелері шоғырланған. Инновациялық белсенділік бойынша республикалық маңызы бар қалалардан басқа посткеңестік кезеңнен өндірістік аймақ болып қалған Қарағанды облысы, ШҚО аймақтар дамуды көрсетеді. Мәдени саласы бойынша барлық аймақтарда 1995 жылмен 2019 жылды салыстырғанда жақсы нәтижелер береді. Қорытындыласақ, мемлекетте даму бар қалалар мен аймақтар анықталды. Өзге аймақтардағы жағдай зияткерлік әлеуеттің көмегімен экономикалық дамуға қол жеткізуге септігі аз. Аймақтардың дамуын бірыңғай дамыту үшін әр аймақтың ерекшелігін ескеріп, сәйкесінше стратегиялық, тактикалық басқару шешімдері қабылдану арқылы экономикалық пайда әкелуге болады. Аймақтардағы зияткерлік әлеуетті көтеру үшін келесідей ұсыныстар беріледі:

- ЖОО білім беру сапасын арттыру мақсатында білім беру стандарттарын күшейту және рәсімдеу шараларын оңайлату;

- ЖОО білім сапасын арттыру мақсатында ЖОО қызметкерлерінің біліктілігін арттыру бағдарламаларын қабылдау;

- ЖОО ғылыми зерттеу жұмыстар сағатын көбейту және аймақтар бойынша университеттер қарамағында ғылыми зерттеу мекемелерін көбейту. Студенттерді ғылымға баулу және қызықтыру шараларын ұйымдастыру арқылы, ғылымға деген қызығушылықты арттыру;

- ғылым мен бизнесті ынталандыру үшін институционалды іс-шаралар қабылдау;

- инновациялық бизнесті дамыту үшін институционалды жеңілдіктерді арттыру (салықтық жеңілдіктер, каникулдар);

- Қазақстан аймақтарындағы табиғи, діни және мәдениет мұрағаттарын ескеріп, туристерді қызықтыру үшін әлемдік деңгейге жарнамалайтын бағдарламалар қабылдау;

- елдер арасындағы қатынастарды нығайтуды дамытатын адам факторының рөлін күшейтуге байланысты қызмет көрсету саласын дамыту;

- мемлекет аймақтарында рухани-мәдениет деңгейін арттыру мақсатында өңірлік бизнес субъектілерін ынталандыруды заң жобасында ескеру және т.б. 


\section{Пайдланылван ддебитеттер тізімі}

1. Цомартова Л.В. (2011). Влияние интеллектуального потенциала на устойчивое развитие региональных социально-экономических систем. Тр. молодых ученых. Владикавказский научный иеентр РАН. Соичология, (1), 137-142.

2. Руткевич М.Н., Левашов В.К. (2000). О понятии интеллектуального потенциала и способах его измерения. Науковедение, (1), 49-65.

3. Лежнина Ю.П. (2006) Взаимосвязь социально-экономических показателей региона с интеллектуальным потенциалом его населения. Труды СГУ. Гуманитарные науки. Психология и сочиология образования, (99), 22-33.

4. MishchukH., RoshchykI., SułkowskaJ., Vojtovic S. (2019). Prospects of assessing the impact of external student migration on restoring country's intellectual potential (the case study of Ukraine). 12(3), 209-219. https:doi:10.14254/2071-789X.2019/12-3/14

5. BilanY., Mishchuk H., Roshchyk I., KmecovaI. (2020). An analysis of intellecutal potential and its impact on the social and economic development of European countries. Journal of competitiveness, 12(1), 22-38. https:doi: 10.7441/joc.2020.01.02

6. Кендрик Дж. (1976). Экономический рост и формирование капитала. Вопросы экономики, (11), 57-71.

7. Кендрик Дж. (1976). Совокупный капитал США и его функционирование. Москва.

8. Нурланова Н. К. (2018). Технологическая модернизацияэкономики регионов Казахстана на основе smart специализации: сценарии и механизмы реализации. Россия: тенденщии и перспективы развития, 13(1). https://cyberleninka.ru/article/n/ tehnologicheskaya-modernizatsiyaekonomikiregionov-kazahstana-na-osnove-smart-spetsializatsiistsenarii-i-mehanizmy-realizatsii

9. Мельдаханова М.К. Приоритеты развития человеческого капитала в условиях инновационной индустриализации Казахстана. https://e-history.kz/ru/history-of-kazakhstan/ show/9348/

10. Калиева С.А., Альжанова Ф.Г. (2019). Молодежь на рынке труда в условиях формирования наукоемкой экономики Казахстана. European journal of economics and management sciences, (4), 56-60. https://cyberleninka.ru/article/n/molodezh-narynke-truda-v-usloviyah-formirovaniya-naukoemkoyekonomiki-kazahstana

11. Сагиева Р., Аленова К., Жупарова А. (2016). Управленческие аспекты модернизации региональной экономики Казахстана. Экономика $и$ статистика, (4), 127-139.

12. Рузанов Р.М., Досманбетова М.С. (2016). Экономические механизмы развития интеллектуального капитала казахстанских организаций. Известия Национальной Академии наук Республики Казахстан. Серия общественньх и гуманитарных наук, (3), 69 - 72.

13. Центр гуманитарных технологий. (20062020). Рейтинг стран мира по уровню образования. https://gtmarket.ru/ratings/education-index/educationindex-info
14. Ваганарова.С. (2014). Оценка влияния высшего образования на социально-экономическое развитие регионов. Проблемы экономики $u$ менеджмента, 1 (29), 23-26.

15. Передовые научные исследования. https://www.tatsachen-ueber-deutschland.de/ru/ kategoriya/obrazovanie-znanie/peredovye-nauchnyeissledovaniya

16. Zhangaliyeva K.N., Korgasbekov D.R. (2020). Intellectual potential of the country: concept, structure and assessment methods. News of the National academy of sciences of the Republic of Kazakhstan. Series of social and human sciences, (4), 84-92.

17. Цвилев Р.И. (1996). Постиндустриальная развитие. Уроки для России. Москва.

18. Министерство национальной экономики Республики Казахстан Комитет по статистике. www. stat.gov.kz

\section{References}

1. Comartova L.V. (2011). Vlijanie intellektual'nogo potenciala na ustojchivoe razvitie regional'nyh social'no-jekonomicheskih sistem. Tr. molodyh uchenyh. Vladikavkazskij nauchnyj centr RAN. Sociologija, (1), 137-142.

2. Rutkevich M.N., Levashov V.K. (2000). O ponjatii intellektual'nogo potenciala i sposobah ego izmerenija. Naukovedenie, (1), 49-65.

3. Lezhnina Ju.P. (2006) Vzaimosvjaz' social'no-jekonomicheskih pokazatelej regiona $\mathrm{s}$ intellektual'nym potencialom ego naselenija. Trudy SGU. Gumanitarnye nauki. Psihologija i sociologija obrazovanija, (99), 22-33.

4. MishchukH., RoshchykI., SułkowskaJ., Vojtovic S. (2019). Prospects of assessing the impact of external student migration on restoring country's intellectual potential (the case study of Ukraine). 12(3), 209-219. https:doi:10.14254/2071-789X.2019/12-3/14

5. BilanY., Mishchuk H., Roshchyk I., KmecovaI. (2020). An analysis of intellecutal potential and its impact on the social and economic development of European countries. Journal of competitiveness, 12(1), 22-38. https:doi: 10.7441/joc.2020.01.02

6. Kendrik Dzh. (1976). Jekonomicheskij rost i formirovanie kapitala. Voprosy jekonomiki, (11), 5771.

7. Kendrik Dzh. (1976). Sovokupnyj kapital SShA i ego funkcionirovanie. Moskva.

8. Nurlanova N. K. (2018). Tehnologicheskaja modernizacijajekonomiki regionov Kazahstana na osnove smart specializacii: scenarii i mehanizmy realizacii. Rossija: tendencii i perspektivy razvitija, 13(1). https:/cyberleninka.ru/article/n/tehnologicheskayamodernizatsiyaekonomiki-regionov-kazahstana-naosnove-smart-spetsializatsii-stsenarii-i-mehanizmyrealizatsii

9. Mel'dahanova M.K. Prioritety razvitija chelovecheskogo kapitala $\mathrm{v}$ uslovijah innovacionnoj industrializacii Kazahstana. https:/e-history.kz/ru/ history-of-kazakhstan/show/9348/

10. Kalieva S.A., Al'zhanova F.G. (2019). Molodezh' na rynke truda $\mathrm{v}$ uslovijah formirovanija 
naukoemkoj jekonomiki Kazahstana. European journal of economics and management sciences, (4), 56-60. https://doi.org/10.29013/EJEMS-19-4-56-60

11. Sagieva R., Alenova K., Zhuparova A. (2016). Upravlencheskie aspekty modernizacii regional'noj jekonomiki Kazahstana. Jekonomika i statistika, (4), 127-139.

12. Ruzanov R.M., Dosmanbetova M.S. (2016). Jekonomicheskie mehanizmy razvitija intellektual'nogo kapitala kazahstanskih organizacij. Izvestija Nacional'noj Akademii nauk Respubliki Kazahstan. Serija obshhestvennyh i gumanitarnyh nauk, (3), $69-72$.

13. Centr gumanitarnyh tehnologij. (20062020). Rejting stran mira po urovnju obrazovanija. https:/gtmarket.ru/ratings/education-index/educationindex-info
14. Vaganarova.S. (2014). Ocenka vlijanija vysshego obrazovanija na social'no-jekonomicheskoe razvitieregionov. Problemy jekonomiki i menedzhmenta, 1 (29), 23-26.

15. Peredovye nauchnye issledovanija. https:// www.tatsachen-ueber-deutschland.de/ru/kategoriya/ obrazovanie-znanie/peredovye-nauchnye-issledovaniya

16. Zhangaliyeva K.N., Korgasbekov D.R. (2020). Intellectual potential of the country: concept, structure and assessment methods. News of the National academy of sciences of the Republic of Kazakhstan. Series of social and human sciences, (4), 84-92.

17. Cvilev R.I. (1996). Postindustrial'naja razvitie. Uroki dlja Rossii. Moskva.

18. Ministerstvo nacional'noj jekonomiki Respubliki Kazahstan Komitet po statistike. www.stat. gov.k

\section{Information about the authors}

* Dana M. Kangalakova - Senior Researcher, Institute of Economics of the Ministry of Education and Science of the Republic of Kazakhstan, Ph.D., e-mail: dmuratbekovna@mail.ru. ORCID ID: https://orcid.org/0000-0001-8388$\underline{8559}$

Dana A. Rakhmetova - Senior Lecturer at S. Toraighyrov Pavlodar State University, e-mail: $\underline{\text { d.life.d@mail.ru. }}$

\section{Авторлар туралы мәліметтер}

* Кангалакова Дана Муратбековна - ҚР БжҒМ ҒК Экономика институтының аға ғылыми қызметкері, Ph.D., e-mail: dmuratbekovna@,mail.ru. ORCID ID: https://orcid.org/0000-0001-8388-8559

Рахметова Дана Аманбекқызы - С. Торайғыров атындағы Павлодар мемлекеттік университетінде аға оқытушы, e-mail: d.life.d@,mail.ru

\section{Сведения об авторах}

*Кангалакова Дана Муратбековна - старший научный сотрудник Института экономики КР MOH PK, Ph.D., e-mail: dmuratbekovna@mail.ru. ORCID ID: https://orcid.org/0000-0001-8388-8559

Рахметова Дана Аманбековна - Старший преподаватель Павлодарского государственного университета им. С. Торайгырова, e-mail: d.life.d@mail.ru 